\title{
Women and scientist: the yellow light on the ivory tower
}

\author{
Zarra Zettina Wiji Riniardi, Trias Setiawati ${ }^{*}$ \\ Department of Management, Faculty of Business and Economics, Universitas Islam Indonesia, \\ Yogyakarta, Indonesia
}

\begin{abstract}
Article History
Received : 20 July 2021

Revised : 20 August 2021

Accepted : 26 August 2021

Published : 27 August 2021
\end{abstract}

Keywords:

Women Scientist (WS), motivation, achievement, gender

*Corresponding author:

trias.setiawati@uii.ac.id

DOI:

10.20885/AMBR.vol1.iss2.art6

\begin{abstract}
The study purposes were to understand the background of women scientist (WS) in studying science, what motivate them to choose science and technology field, exploring their achievement, understanding their social support, exploring their problems. This research was qualitative case study approach. The key informant were four who come from Industrial Engineering and Mathematics and Science Faculty of Universitas Islam Indonesia. The data collection method used depth interviews, observation and documentation. The data test method used triangulation while analysis uses reduction-display-conclusion. The research found that WS studied science because of their interest of internal factor and the environment role of external factor. Their motives also gave benefit for others and increase their networking that is bit similar to McClelland's Theory. WS had high excellent achievement in functional and structural positions, they received awards from their university until international award which are related to their research result. They also occupied important university structural position. They faced role conflict problem which similar to Greenhaus and Beutell (1985) Theory which increase their behavior changing. They faced marginalization because of their marital status and fear of success tendency which are losing cooking skills and having risk of not having friends which similar to Shaw and Costanzo (1982) Theory.
\end{abstract}

\section{Introduction}

Women in gender definition is considered to have the nature of gentle, graceful, maternal, emotion and so on (Fakih, 1996) so that there is a presumption of women have a domestic role, which is taking care of households (Vitayala and Hubeis, 2010). Women who decide to work generally because of financial reasons and forms of self-actualization. another form of self-actualization of women is to pursue their interests and talents since their childhood, including those who in grace have the cognitive ability, especially in mathematics. Women scientists are often born from the environment that formed them. American Asociation of University Women or AAUW (2010) stated that the achievements and interests of women in mathematics and science were shaped from the surrounding environment. Empirical studies showed that Science and technology help the country's development. Murphy et al., (1991) stated that countries with a higher proportion of engineering graduates tend to grow faster than countries with a higher proportion of graduates in other disciplines.

Improving women and science role in the country development will effect the welfare of a country. Diversity increases the possibility of innovation. European Commission (2005) stated that diversity requires gender equality, the phenomenon of gender equality in science and technology is not just about justice, gender equality in science and technology will increase the chances of getting the most talented people during recruitment, regardless of gender. National academy of Science (2006) also stated the similar one that selecting some of the resources that have not been exploited in a more inclusive workforce is assumed to be more innovative and productive than those that are not. 
Women scientist need some support to achieve their success. Szelenyi and Inkelas (2011) found that men outperformed amount of women in the science and technology profession, both at the university level and at work. Women who survive for a career in male-dominated science and technology have several factors such as: high efficacy, they describe their identity as an engineer, and motivated by the challenges and novelties of their profession. Buse et al., (2013) said that the ability of female engineers to adapt allows them to survive and thrive even though working in a male-dominated culture is characterized by workplace-related difficulties, including discrimination. Valk et al., (2014) stated that the career motivation of female scientists are based on the recognition of peer in science, satisfaction and able to contribute to the science and society of India.

Women in science and thechnology have some challenges to achieve their best performance. Trowbridge and Byebee (1986) stated that being a female scientist is not easy, being a scientist is a lifelong dedication to science, continuous and endless because the definition of science itself is "science is a body of knowledge, formed by a process of continuous inquiry, and encompassing the people who are enganged in the scientific enterprice." Based on these definitions, the distinctive characteristic of science is that science is pursued through continuous inquiry processes that contribute in various ways to form a unique system. Research is like an opiate for scientists and willing to sink completely into it.

Women in sciene and technology have some burdens that are not only in their public life but also in domestic life. Another problem of female scientists in the early 80s was recognition, Gornick (1988) gave the term "half in half out" to meritocracy at certain scientific and technological institutions the meaning is "occupying the periphery of a scientific system is still better than not being part of the system at all." Meritocracy in science and technology institutions will bring about other issues related to gender issues (Goldberg and Hill, 2007). Gender gaps in science and technology often create gender inequalities caused by some of them: Work segregation accounts for most wage gaps.

Women in science and technology in Indonesian university have many duties. It is not only about their research but also their education and teaching activities, and community service, it is called Tri Dharma Perguruan Tinggi or Three Main University Duties (TMUD). Universitas Islam Indonesia (UII) is the oldest university in Indonesia. UII was originally named Sekolah Tinggi Islam (STI) which was established in Jakarta on the day of 27 Rajab 1364 Hijriyah coinciding with the date of July 8, 1945, based in Yogyakarta. UII vision is the realization of Rahmatan lil'Alamin, it has a commitment on perfection and Islamiyah treatise in education, research, community service, and da'wah islamiyah. For the implementation of education at UII, UII has Catur Dharma Perguruan Tinggi or Four Main University Duties (FMUD) which consist of: Education and Teaching, Research, Community service, and Da'wah Islamiyah (UII, 2009). That is why women lecturer in science and technology, especially in Universitas Islam Indonesia have not only three main duties but also have more that is FMUD. Is it ok for them to do their best in FMUD? Based on this background the author was interested to conduct a research on women in science and technology with some purposes were: 1) Understanding the backgrounds of women in science and tehcnology (WST) for studying science, 2) Exploring the motivation of WST, 3) Understanding the achievements of WST, 4) picturing the social support of WST, 5) Exporing the problems that were faced by WST.

\section{Literature Review and Hypotheses Development}

Research conducted by Dasgupta and Stout (2014) indicated that the importance of the learning environment, relationships and family characteristics will be opportunities for women's interest, achievement and enhancement and women's participation in STEM. Lindsey (2011) study's showed that not all of the women who study science come from parents with its educational background, in the meaning that women learn science because they have an opportunity in learning science, in other words public role (university or institution) also plays a role in motivating women in learning science. 
The study that had been done by Edzie (2014) concluded that the factors that influence undergraduate to choose STEM were helping their careers, having access in college, acquiring relationships with influential stakeholders and the latter developing confidence in mathematics and science. Research that conducted by AAUW (2010) concluded that there are three main factors that cause why there are few women in STEM, the three factors are: 1) Environment, achievement and interest of women towards mathematics and science were formed by their environment. 2) The role of high schools and universities, 3) Bias, which often unconsciously limits the development of women in the STEM field. Research by Buse et al., (2013) shown that women who survived in their articulated engineering careers had had high levels of self-efficacy, motivated by the challenges and novelty of their profession.

Research by Valk et al., (2014) concluded that the recognition of fellow colleagues in science and technology, satisfaction and can contribute to the science and society of India is the motivation of the successful career of expatriate women in India. Research that was conducted by Coatesworth (2015) show that there are 5 possible female motivational features that persist in STEM: individual needs and priorities, direct manager influences on development, workplace policies based on performance and organizational culture that are continuously pursued, an important anti-bias movement, and an increasingly challenging career path.

Dimitri (2013) in his research showed that career orientation is offered since they are in college, family, parents, and mass media has become an important role that affect women's career choices in science and technology. Research by Katz et al., (2006) showed that at the level of achievement predicted by Aptitude Test Scores (ATS), a calculus course was taken before taking a computer science course, the number who have home computer access, computing experience, and mentors during high school.

Fox et al., (2011) showed that gender is one of the factors influencing the occurrence of conflict of role of family, marriage, child, work, difference of seniority, kind of work because those factors cause the work family role conflict. Research by Rice et al., (2013) concluded that social support has an indirect effect on students' behavior on mathematics and science. Other research results showed that students who have better social support for mathematics and science from parents, teachers, and friends have a positive attitude and a higher sense of competence in the subject of science and math lessons.

Uzoigwe et al., (2016) in his research indicated that the cause of conflict of family work role is burn-out caused by work pressure. Research by Buday et.al, (2012) concluded that social support direct the ability and envisions themselves in future science careers that back to their motivation in the field of science and technology. Research by Riffle et al., (2013) showed that the reality is that women are as productive as men. Several women's reports indicate that institutions perceive that women are less productive than men, less influential than men and and sexism and gender discrimination in STEM Institution.

Lincoln et al., (2012) suggested that women get professional award and rewards that increase for two decades than men, but fewer at higher levels than men. Carli et al., (2016) concluded that women are considered to lack their skills that are needed to be successful scientists and then it can contribute to decrease the discrimination and prejudice against female scientists. This research would expore the life of some women in science and technology in university.

\section{Research Methods}

The research approach used in this research was descriptive qualitative approach using case study with deep data collecting through in-depth interview, observation, and document collection both visual and audiovisual to interviewees. The location of the research was conducted in Universitas Islam Indonesia, Yogyakarta. UII is the oldest university in Indonesia. UII was originally named Islamic high school founded in Jakarta on the day of 27 Rajab 1364 Hijriyah coinciding with the date of July 8, 1945, based in Yogyakarta. Research had used four main key informants from Fakultas Matematika dan Ilmu Pengetahuan Alam (MIPA) or Mathematics and Science Faculty, Fakultas Teknologi Industri (FTI) or Industrial Technology Faculty (both from Informatic 
Engineering), the four women were permanent lecturers in their department, two informants are married and two are not married yet.

\section{Research Instrument}

According to Lincoln and Guba (1985) in a qualitative study, which became the instrument or tool of research is the researchers themselves. Therefore, the researcher as an instrument must also validated how far qualitative researchers are ready to conduct research then enter into the field.

\section{Women Study Science's Background}

Reason why student were learning and are driven by extrinsic and instrinsic motivation. This research were focused to explore why are they study mathematics and science since their chilhood, who plays a role in their interests, their experience while study, achievement in their study, educational level.

\section{Career Motivation of Women Scientist}

Women had motive to build career that based on their interest that are driven by high level motivation such as achievement and affiliation. This research were focused to explore: the early begining motive why women choose science and technology field, what werw interesting factors to become a scientist, what is something to be achieved as a scientist, self motivation, economic factor, environment role, career decision making, the need of WST, effort to meet the needs of WST, opinion about succesful WST, opinion about their barrier as WST, an opinion about gender stereotype of WST. WST opinion about gender discrimination, marginalization, fear of being succesful as WST.

\section{Achievement of Women Scientist}

Achievement often called as well achieved target. Based on provisions of Koordinator Perguruan Tinggi Swasta (KOPERTIS) or Private University Coordinator (PUC) and STATUTA UII (2009), the achievement of scientist as lecturer assessed by the main task of lecturer (TMUD and FMUD), this study were focused to explore the teaching activities, educational background, how many research were conducted by WST (proceedings, published journal, books, being speaker, certificate of expertise, award and extc), how did WST perform in their public service tasks and their programs for it, how did WST perform da'wa islamiyah.

\section{Problem Faced by Women Scientist}

The career barrier for women that often come from bias, stereotype, discrimination, fear of success and often dual role conflict, this study focused to understand: problems in the office/campus, problem as married women or unmarried yet, work distress outcome and its effect for women, family distress outcome and effect for women, gender discrimination, violence, people opinion about WST, fear of succes tendency: ability to socialize with neighbord, skills related husehold, marginalization among scientist, the outcome of work-family distress, how did WST manage their time.

\section{Social Support for Women Scientist}

The social support often comen from family or people who have a huge contribution in their life, this study were focused to understand: people with a huge contribution in their life, how did WST overcome distress of dual role conflict, how did WST get their motivation from people around them, what form of encouragement that were given by people around them, how encuragement are work for WST distress. 


\section{Collecting Data Method}

This study used (1) Interview, (2) Obsevation, and (3) Documentation. Interview according to Creswell and Creswell (2017), interview is a meeting of two people to exchange information and ideas through question and answer so that it can be constructed meaning in a certain topic. In this study the interviews used semi-structured interviews where the researcher had interview questions as a guide but the discussion would develop with the spontaneous questions that emerged throughout the interview.

\section{Data Analysis Techniques}

The process of data analysis wss done before entering the location of research and data analysis is in the field. Creswell and Creswell (2017) after getting the data in the field, the researchers conducted a qualitative data analysis process namely; data reduction, data presentation, and drawing conclusion.

This research used the validity test data: credibility test, testing the credibility of this study using triangulation. Triangulation in testing this credibility is interpreted as checking data from source sharing in various ways and at various times. Thus triangulation is divided into three: sources, techniques, and time. (Creswell and Creswell, 2017). Transferability test is an external validity in qualitative research. External vadilitas shows the degree of accuracy. (Creswell and Creswell, 2017).

\section{Results and Discussion}

\section{Women Learning Science's Background}

This study found that the overall background of women study of science and technology were interests, they liked Mathematics since their childhood. Is Fatimah (IF) had good exact skills since her childhood, so it is possible to pursue her field today. So is Mrs. Izzati (IZ) who loves mathematics since her childhood.

"I used to like mathematics, then when early in college I took Electrical Engineering and Nuclear in UGM, habahah is it absurd, right?" (Muhimmah, 12/10/2016, 11:35)

The second reason was the four speakers came from families with a background of teacher so that they affect their little girls' interest in learning science and technology. As one of the informant said as below testimony.

"If it was because of my parent blood is teacher (decendant of the teacher)" (Kusumadewi, 19/10/2016, 09.07).

When Ms. Kusumadewi (KS) asked about why she deepens her current profession then her answer is because of the influence of her parents profession. Similarly, Ms. Rosa (RS) who deepens her field today because she wass influenced by her sibling. IF and IZ were motivated by their professors and their supervisors while in college and the others two are not. Two of them were motivated by external environment and the other two are internal motivation.

The results of this study strenghtened the result of previous studies that was conducted by AAUW (2010) which conclude that the their child environment and their professor's university has influenced the girls' interest in early career and in learning science. This research was similar to Edzie (2014) who concluded that educational policies, specialization programs and educator roles are factors that influence and motivate the women to exist and survive in science at the college level. This research had strengthened Dasgupta and Stout (2014) research which concluded that the learning environment, relationships and family characteristics are the ones that give that girls the opportunity to learn science.

The different study that had been conducted by Lindsey (2011) conclude that their parents do not have significant influence on their daughter's interest in learning science, the results of this research are slightly contrary to this research that the parents do have a role in their daughter's interest in learning science. So it could be concluded that the parent can have or have 
not influence to their daughter's in learning science and technology while the more researches which the parent have the influence toward their daughters in learning science

\section{Careers Motivation of Women Scientist}

Some women did their activities and are driven by something that is called motivation, this motivation is what drive women into the field of science and technology. This study showed that the dominant factor of the career of women scientiest in science and technology are giving benefit to others. IF said that the majority scientist's goal are to give benefits for others, as well as KS said that she want to make her research useful for her nations.

"My research must be useful for my nation and not for others nation, so then If I do my research that is a research that is useful for others." (Kusumadewi, 19/10/2016, 9.07)

Except providing benefits to others, building relationships was very important for a women scientist.

"I was very diligent to have social network, there is attending wedding party, even only asking to a new lecturer what is your job mam? Doctors may not necessary yet, but it may be later if there is a student who is doing dissertation can be contacted again. There was a new lecturer or not? So that I need to know, once there are acquaintances so then I ask; for now, is there panatomy analogy? Because all the project I did it with UMY lecturer, I was struggle for long distance to go for it but now there are some lecturers who already come back to UII with same expertise." (Muhimmah 12/10/2016, 11:35)

IZ was very passionate about getting acquainted and building relationships with new people. In addition to build relationships and providing benefits to others, personal factors such as pleasure and happiness that is gained in the profession become one of her motivations that drive her career in science and technology. RS also believed that what she had been done so far it is because she is happy. RS said that her motive is to make her parent happy including one of the factors that motivate herseld to have career in science and technology as well as what is proposed by IZ.

This result almost similar with the research result that have been conducted by Buse et al., (2013) which conclude that self-efficacy, motivated by new challenges and adaptability are the women motivation for surviving in their careers as scientists, Coatesworth (2015) stated that individual needs, workplace influences (policy, organizational culture, management), career paths are clearly the reasons why women have their career in science and technology. Dimitri's (2013) research showed that career orientation was existed by some universities, families, parents and mass media become the important role to support womens' career in science and technology.

\section{Achievement of Women Scientist}

Lecturers also were known as scientists who have the tasks of transforming, developing, and transforming science-technology, and art through education, research and community service. As scientists, lecturers often conducted some researches. This study explored the scientist's achievements on their respective fields. Four key persons in this study received university, national, until international awards for their achievements as lecturers and researchers. For international awards, IF was awarded by L'Oreal-UNESCO for Women in Science in 2011. In addition to international awards IF also received many awards both inside university level and also in national level. In the the national award, KS had become one of the 15 achievement lecturers finalist in the national level that was conducted by the Indonesia Higher Education Ministry in 2005, not only that award KS also was known who publish many books which related to Information Systems subject.

".. in early of year 2000, her informatics books was published in english language, there is no books in bahasa, for example furay, there is no book in bahasa. And well she is the pioneer (writing books in bahasa) and yes it is difficult (to find informatics) books in bahasa." (Daniyati, 26/11/16, 16:04) 
In addition to KS, IZ was also awarded by Intel Indonesia for her activity in developing robot teams and was crowned as Kartini Indonesia (Intel Indonesia Version). The achievements of female scientists in this study were very amazing, they get award from unversity level, national level until international level for their research achievements. Not only in the field of science, they are also occupied in some structural important inside the university until now. It were recorded that IF is the department head of Chemistry study program, IZ is the head of medical informatics research, KS is the Vice Dean of Industrial Engineering Faculty, while RS has no structural position on campus because she is a new doctor graduation. Although WS had high achievements in the field of research and teaching, but she has low performance in public service and da'wah Islamiyah.

Research by Lincoln et al., (2012) stated that number of women who achieve professional award have increased for two decades more than men, but they are fewer at higher levels than men. Finding in this result was a bit similar with some of the previous research result that women have a high performance in science and technology.

\section{Social Support for Women Scientist}

In one side this study found that greatest support for the married women scientist come from their spouse in the form of permit, but in another side for the single women scientists come from their parent as their greatest supporter. IF and IZ were married, especial for IZ the support come from her husband is more than his permit but a deal that bring consequence to obey.

"I was permitted, but yes there is a price, it must prioritize, so now I have consequences after teaching and taking care my kid (pick ther daughter from school) I have to back home at half past three, I just can not stay until ashar time so I can't because he can't (probibited). Sometime I broke abit (the rule), the employees went to office at 8 AM until - I was at 9 AM, and off at 4 PM-for me I should off halfpast three. (Muhimmah, 8/11/2016, 20:47)

Different with IZ situation, IF got the full support from her husband, even her husband also have responsible for taking care their children and their household. For both RS and KS, their parent support were in the form of praying for them and understand them such as they do not want to disturb their daughter's activities. What they said that related their daughters.

"Yes my mother, even my mother she do not disturb, if there is any work in my office I have to finish first, "do not have to think about me." (Kusumadewi, 19/10/2016, 09.07 WIB).

This study was almost same with several previouus studies that have been conducted by Rice et al., (2013) which the results that social support affect the women competence in science and technology. Buday et.al, (2012) with the results that social support affect the women career choice in science and technology. Dasgupta and Stout (2014) was also the same results that the learning environment, relationships and family characteristics will provide opportunities for the interests, achievements and enhancement of women's participation in science and technology. Dimitri (2013) found the same that career orientation outcomes are described by college, family, parents and mass media that become an important role that affect women's choice in science and technology.

\section{Problems Faced by Women Scientists}

This study showed that in the life problem of married scientists were dual role conflict; work-family and structural position-academic position, and also they do overtime. As information that was obtained from RS who always stay overnight in campus to finish her work. In the matter of time, KS found her difficulties in its management between become a vice dean and write a book which has stopped for a long time. While IZ experienced that she is hard to focus in doing her research and writing a book because of family matter and some university activities.

"I could not focus fast, in writing a book. I must in calm or cool condition or something, so in this time it is impossible to be cool and calm because of routines tasks and other activities." (Muhimmah 12/10/2016, 11:35) 
Another problem was faced by IF is discrimination among the professionals, the Professor title that should be pinned to her name is not given yet untill now.

"If it was about the point amount, I am over (qualification), yea I do not even know why, but I try to ask University head what is happened to my qualification that is rejected to be Professor, they certainly can not answer that." (Fatimah, 17/10/2016, 14:05).

In addition to discrimination issues of IF, RS also admitted to her experience in discrimination and marginalization due to her marital status that not married yet.

"Sometimes marginalization also occured because I am unmarried. (Rosa, 16/10/2016, 13:10)"

The other experience of marginalization, RS also suffered mental violence in her work. Due to her busy life, IZ also has a problem for accepting the risk of not having friends. Work distress often affect on women emotion and behaviour even they are at home.

"I did not participate intentionally in social gathering, so in the future I have to accept the risk of not having a friend." (Muhimmah 12/10/2016, 11:35).

The results of this study was almost similar with the results of presvious research that had been conducted by Riffle et al., (2013) that women are considered less productive than men and they discovered of sexism in the workplace. The other research that was conducted by Uzoigwe et al., (2016) show that the work pressure can cause wor-family role conflict. This research was also supported by Fox et al., (2011) which conclude that gender is one of the factors influencing the occurrence of family work role conflict, whereas marriage, children and seniority differences become factors for work-family role conflict. This research was supported by Carli et.al., (2016) which conclude that women are considered lack of the skills needed to be successful scientists that con contribute to discrimination and prejudice against WS.

The four women scientist was colourful with many awards and achievement. They did many researches, writing books, had amazing honoroble achievements until the world level. The did not only three main university duties (TMUD) but also for main university duties (FMUD). They had so much knowledge and expertise as the valuable ivory in an elephant. They had valuable dignity as the women scientists in science and technology. In one side they had so many valuable advantage but in another side they have some challenges and limitations to express their capacity as the women scientists in science and technology (WSIST). They can do many matters that related to giving benefit to others, not only for their university life but also for their nations and science's world.

Their live was very valuable as the queen that had been crowned in tower of the kingdom. Their advantage and the benefit that can be shared were looked liked yellow light. Their knowledge and their creation in the science and technology world were the kingdom of wise and dignity. They were looked like many queens and princess in the ivory tower. Even they had limitations to do their best in community services and da'wah Islamiyah for their TMUD and FMUD but they have yellow light of dignity in the ivory tower.

Based on finding, this study can be stated as "Women scientiest: The yellow light on the ivory tower." The light reflected on their knowledge, science and technology as the knowledge that can enlighten people's mind. The yellow light reflect on how their achievement, in the hystory of China yellow colour is figure of honour, glory and greatness. The ivory tower was reflected their posisition and their scientist life, they sat as high as ivory tower but have difficulties to socialize to people around them.

\section{Implication and Conclusion}

Based on the analysis and discussion the following are the conclusion of this study: First, this study found the intrinsic factors of women scientist are interest in mathematics since their childhood, whereas the extrinsic motivation were role of family members and their collegeau's lecturer in their university. These findings were similar to the Intrinsic factor stated by Firdausz (2012) and the exstrinsic factor that was stated by Suciati and Prasetya (2001). Second, there were 
two dominating motivation of women scientiest in UII, there were giving benefit to others, and build networking. This finding were similar to theory which is stated by Sumarwan (2004) that the basic need are three; the need for success, the need for affiliation and the need for power. In addition of women scientist motivation, they also motivated by personal factors such as pleasure, happiness, and make their parent are happy.

Third, the achievements of wome scientists were very amazing, they get some awards from their universities, national level, until international level and also are occupied by the unvesities that give them main positions in university structural positions and they are consistent to become humble and low performance in public service and da'wah Islamiyah. Fourth, social support for the married women came from their husbands in permit form while the unmarried ones come from their parents in the form of emotional support. The results of this study were similar to the concept which is stated by Sarafino and Smith (2014) in the five forms of social support are: emotional support, award support, instrumental support, and information support. Fifth, the main problems that arise from women scientists were time constraints, emotion, gender inequality in the form of marginalization, mental violence, multiple workloads. Another problem was they have no friends. This finding were bit similar to concept which is stated by Fakih (1996) that manifestation of gender inequality are marginalization of women, subordination, stereotype, violence, and multiple workloads. It was also similar to Shaw and Costanzo (1982) who stated that fear of success are lost of feminity, lost of special self esteem, and social rejection. The problem findings were also similar to Greenhaus and Beutell (1985) that defined three types of work-family conflict which are time-based conflict, strain-based conflict, and behavior-based conflict.

This research was a case study approach on motivation and achievement of women scientist. This study concluded that women scientist have amazing achievement in research and teaching activities, but they had lack of contribution in public service and da'wah Islamiyah. This study also concluded that they face some problem that related to their scientist life, almost of them had experience in difficulties to manage their time and dual role conflict, family-work and structural-academic role, their distress leads them to a risk of having neither friends nor lack of time to socialize and become close with their family. Based on finding, this study can be stated as "Women scientiest: The yellow light on the ivory tower." The light reflected on their knowledge, science and technology as the knowledge that can enlighten people's mind. The yellow light reflect on how their achievement, in the hystory of China yellow colour is figure of honour, glory and greatness. The ivory tower was reflected their posisition and their scientist life, they sat as high as ivory tower but have difficulties to socialize to people around them.

This research had been done completely for women scientist in the field of Science and Technology, so for the further research, it is expected to be conducted study of women scientist in another universities or in social science field, these author hope the research can give the contribution for science especially in Human Resource Manegement and become references for the future researches.

\section{Acknowledgements}

We appreciated so much to Pusat Pengembangan Manajemen [The Management Development Centre] of Management Department of Universitas Islam Indonesia which give us a research fund to do this research collaboration between the lecturer and the student who do the final assignment for finishing the study. This research publication also will be funded by Pusat Pengembangan Manajemen and The Academic Development Board of Universitas Islam Indonesia. We are highly appreciate to this chance to publish it.

\section{References}

AAUW (American Asociation of University Women), (2010). Research Report: Why So Few? Women in Science, Technology, Engineering, and Mathematics. United Stated. AAUW Publishing.

Buday, S. K., Stake, J. E., and Peterson, Z. D. (2012). Gender and the choice of a science career: The impact of social support and possible selves. Sex Roles, 66(3-4), 197-209. DOI 


\section{$10.1007 / \mathrm{s} 11199-011-0015-4$}

Buse, K., Bilimoria, D., and Perelli, S. (2013). Why they stay: Women persisting in US engineering careers. Career Development International, 18(2).

Carli, L. L., Alawa, L., Lee, Y., Zhao, B., and Kim, E. (2016). Stereotypes about gender and science: Women $\neq$ scientists. Psychology of Women Quarterly, 40(2), 244-260.

Coatesworth, M.G. (2015). Women staying in STEM Professions Long-term: A Motivational Model. UMI Dissertation Publishing.

Creswell, J. W., and Creswell, J. D. (2017). Research Design: Qualitative, Quantitative, and Mixed Methods Approaches. United States: SAGE Publications.

Dasgupta, N., and Stout, J. G. (2014). Girls and women in science, technology, engineering, and mathematics: STEMing the tide and broadening participation in STEM careers. Policy Insights from the Behavioral and Brain Sciences, 1(1), 21-29. SAGE publication online.

Dimitri, A. (2013). Young Women in Science and Technology: the Importance of Choice, Journal of Innovation and Entrepreuneurship, 2(1), 1-14.

Edzie, R.L., (2014). Exploring the Factors that Influence and Motivate Female Students to Enroll and Persist in Collegiaate STEM Degree Programs: A Mixed Method Study. Educational Administration: Theses, Dissertation, and Student Research Paper 171.

European Commission (EC). (2005). Women and Science: Excellence and Innovation- gender Equality in Science. Commission Staff Working Document, Directorate-General for Research, Structuring the European Research Area, Science and Society, European Communities.

Fakih, M. (1996). Analisis Gender dan Transformasi Sosial. [Gender Analisys and Social Transformation]. Yogyakarta: Pustaka Pelajar.

Firdausz, R. (2012), Motivasi Mahasiswa Bergabung di Organisasi Intra Kampus, [Student Motivation Joint in Inter Campus Organization]. Publised Undergraduate Thesis, Semarang: Fakultas Ekonomika dan Bisnis UNDIP.

Fox, M.F., Fonseca, C., and Bao, J. (2011). Work and family conflict in academic science: Patterns and predictors among women and men in research universities. Social Studies of Science, 41(5), 715-735. http://journals.sagepub.com/doi/abs/10.1177/0306312711417730.

Goldberg, J., and Hill, C. (2007). Behind the pay gap. AAUW Educational Foundation Publishing. https://www.aauw.org/files/2013/02/Behind-the-Pay-Gap.pdf

Gornick, V. (1988). Perempuan dalam sains: Gambaran suatu dunia dalam masa peralihan [Women and Science: the Description in Changing Era]. Translated Edition. Jakarta: Pustaka Dinar Harapan.

Greenhaus, J.H., and Beutell, N.J. (1985). Sources of Conflict between Work and Family Roles. The Academy of Management Review, 10(1). https://www.jstor.org/stable/pdf/258214.pdf

Katz, S., Allbritton, D., Aronis, J., Wilson, C., and Soffa, M. L. (2006). Gender, achievement, and persistence in an undergraduate computer science program. ACM SIGMIS Database: the DATABASE for Advances in Information Systems, 37(4), 42-57.

KOPERTIS. (2014), Jabatan Fungsional Dosen dan Angka Kreditnya. [Functional Position of Lecturer and Credits]. http://www.kopertis13.org/upload/e-pnl-dosen.pdf

Lincoln, A. E., Pincus, S., Koster, J. B., and Leboy, P. S. (2012). The Matilda Effect in science: 
Awards and prizes in the US, 1990s and 2000s. Social Studies of Science, 42(2), 307-320. http://journals.sagepub.com/doi/abs/10.1177/0306312711435830

Lincoln, Y.S., and Guba, E.G. (1985). Naturalistic Inquiry. London: SAGE Publications.

Lindsey, L.L. (2011). Gender Roles: A Sociological Perspective, 5th edition. New York, USA: Pearson Education, Inc.

Murphy, K. M., Shleifer, A., and Vishny, R. W. (1991). The allocation of talent: Implications for growth. The Quarterly Journal of Economics, 106(2), 503-530.

National Academy of Science (NAS). (2006). To Recruit and Advance: Women Student and Faculty in U.S Science and Engineering. Washington DC: National Academies Press.

Rice, L., Barth, J. M., Guadagno, R. E., Smith, G. P., and McCallum, D. M. (2013). The role of social support in students' perceived abilities and attitudes toward math and science. Journal of Youth and Adolescence, 42(7), 1028-1040.

Riffle, R., Schneider, T., Hillard, A., Polander, E., Jackson, S., DesAutels, P., and Wheatly, M. (2013). A mixed methods study of gender, STEM department climate, and workplace outcomes. Journal of Women and Minorities in Science and Engineering, 19(3), 227-243.

Sarafino, E. P., and Smith, T. W. (2014). Health psychology: Biopsychosocial interactions. NYSE, USA: John Wiley \& Sons.

Shaw, M.E., and Costanzo, P.R (1982). Theories of Social Phychology. Kogakusha: Mc.Graw Hil, Inc.

STATUTA UII 2009.

Suciati, and Prasetya, I. (2001). Teori Belajar dan Motivasi [Learning Theory Motivation]. Jakarta: Depdiknas, Ditjen Dikti.

Sumarwan, U. (2004., Perilaku Konsumen [Consumer Behavior], Bogor: Ghalia.

Szelenyi, K., and Inkelas, K.K. (2011). The role of living-learning programs in women's plans to attend graduate school in STEM fields. Research in Higher Education, 52(4), 349-369.

Trowbridge, and Byebee S. (1986). Becoming s Secondary School Science Teacher. Third Edition. Ohio: A Bell \& Howell Company.

Uzoigwe, A. G., Low, W. Y., and Noor, S. N. M. (2016). Predictors of work-family role conflict and its impact on professional women in medicine, engineering, and information technology in Nigeria. Asia Pacific Journal of Public Health, 28(7), 629-637.

Valk, R., Van der Velde, M., Van Engen, M., \& Godbole, R. (2014). International career motives, repatriation and career success of Indian women in Science \& Technology. Journal of Global Mobility, 2(2).

Vitayala, A., and Hubeis, S. (2010). Pemberdayaan Perempuan dari Masa ke Masa [Women Empowerment from Time to Time]. Bogor: IPB Press. 